\title{
Recognition of Secondary Structures in Proteins by a Diiron(III) Complex via a Hydrolytic Pathway
}

\author{
Qunhui Pan ${ }^{1}$ Wei Jiang ${ }^{1}$ Zhanru Liao ${ }^{2}$ Tianle Zhang ${ }^{1}$ Changlin Liu ${ }^{1}$ \\ 1, Department of Chemistry, Huazhong University of Science and Technology, Wuhan 430074, Hubei China; \\ 2, Department of Chemistry, Huazhong Normal University, Wuhan 430079,Hubei China. \\ E-mail: liuchl@mail.hust.edu.cn for Changlin Li
}

\section{EXPERIMENTAL PROCEDURES}

The diiron(III) complex $\mathrm{Fe}_{2}$ was synthesized according to the previously reported methods. ${ }^{1}$ The proteins human Hb, BSA, Lyso, bovine pancreas RNase, and SOD were B.M, SanLand, AmResco, Sigma, and Roche product, respectively. Guanidine hydrochloride $(\mathrm{GdnHCl})$ was purchased from Sigma. All other reagents utilized here were the highest grade from Sigma and Acros. All sample solutions were prepared using distalled water that had been passed through a Millipore ultrapurification system.

The absorption spectra of $\mathrm{Fe}_{2}$ and its interactions with each protein were determined by electronic absorption spectra recorded at $25{ }^{\circ} \mathrm{C}$ on a Perkin-Elmer Lambda Bio 4.0 UV-visible spectrophotometer. The apparent binding constant $K_{\mathrm{b}}$ between $\mathrm{Fe}_{2}$ and each protein was obtained on the basis of the variations in the absorbance of $\mathrm{Fe}_{2}(19.4 \mu \mathrm{M})$ at $211 \mathrm{~nm}$ with concentration of the protein. The concentration of each protein was varied $(0-67 \mu \mathrm{M})$ in $20 \mathrm{mM}$ HAc-NaAc buffer, pH5.6, until saturation points appeared in the obtained absorption spectra. The reaction for each titration was performed for $1 \mathrm{~min}$ prior to measurement. From the binding plots derived from the absorption data, the apparent binding constants were obtained according to the previously reported fitting method. ${ }^{2}$

Circular dichroism (CD) was recorded on a Jasco model J-810 spectropolarimeter using a cylindrical cell of $1 \mathrm{~cm}$ optical path length between $180-250 \mathrm{~nm}$ at $25{ }^{\circ} \mathrm{C}$. Each spectrum represents the average of four accumulations at scanning speed of 200 $\mathrm{nm} / \mathrm{min}$, a $1.0 \mathrm{~nm}$ spectral bandwidth, a data pitch of $0.1 \mathrm{~nm}$ intervals and a response time of $16 \mathrm{~ms}$. The experiments were performed by using $0.25 \mu \mathrm{M}$ of each protein and variable concentration (0-9.12 $\mu \mathrm{M})$ of $\mathrm{Fe}_{2}$. The influence of added $\mathrm{Fe}_{2}$ on the structures of each protein was monitored by changes in $[\theta]$ $\left(\mathrm{deg} \cdot \mathrm{cm}^{-1} \cdot \mathrm{L} \cdot \mathrm{mol}^{-1}\right)$. The spectra of each sample were corrected by subtraction of that of the buffer alone. The fractional changes in secondary structures of each protein were estimated by software Secondary Structure Estimation attached to the instrument, based on molecular ellipticity $([\theta])$ of each sample.

The hydrolytic reaction of each native and denatured protein was carried out according to the following procedures under the aerobic and anaerobic conditions. The $\mathrm{Fe}_{2}(0-200 \mu \mathrm{M})$ was incubated for $48 \mathrm{~h}$ at $50{ }^{\circ} \mathrm{C}$ with native forms of $15 \mu \mathrm{M} \mathrm{Hb}, 15$ $\mu \mathrm{M}$ BSA, $17 \mu \mathrm{M}$ Lyso, $7 \mu \mathrm{M}$ RNase, and $6 \mu \mathrm{M}$ SOD, respectively, in $20 \mathrm{mM}$ HAc-NaAc buffer, pH5.6. To compare the degradation reactions of both native and denatured forms of these proteins under the experimental conditions, we assayed the hydrolysis of partially denatured proteins mediated by $\mathrm{Fe}_{2}$. The denatured form of each protein was produced by treatment for 24 $\mathrm{h}$ at $25{ }^{\circ} \mathrm{C}$ in the buffer containing $5.9 \mathrm{M} \mathrm{GdnHCl}$ and $1.67 \%(\mathrm{v} / \mathrm{v})$ 2-mercaptoethanol. However, partial refolding of the denatured proteins can take place, when the concentration of the denaturant was reduced from 5.9 to $1.9 \mathrm{M}$ due to dilution. ${ }^{3}$ The $\mathrm{Fe}_{2}(0-800$ $\mu \mathrm{M})$ was incubated for $24 \mathrm{~h}$ at $50{ }^{\circ} \mathrm{C}$ with these resulted partially denatured forms of $147 \mu \mathrm{M}$ BSA, $143 \mu \mathrm{M} \mathrm{Hb}, 170 \mu \mathrm{M}$ Lyso, 71 $\mu \mathrm{M}$ RNase, and $28 \mu \mathrm{M}$ SOD, respectively, in the buffer. The protein hydrolysis experiments performed under the anaerobic conditions include: (1) all sample solutions were deoxygenated by pure argon flow, and (2) the reactions were covered with mineral oil, and then the argon-filled tubes containing the reactions were covered by parafilm.

The hydrolytic reactions of both native and partially denatured forms of the proteins were monitored by SDS-PAGE (sodium dodecyl sulphate-polyacrylamide gel electrophoresis) and LCESI-MS (liquid chromatography-electrospray-mass spectrum). Reactions were first quenched by cooling to room temperature. Then, at the end of these reactions, the samples were loaded onto $10 \%$ (for BSA) or $15 \%$ (for other proteins) PAGE gels and constant voltage of $80 \mathrm{~V}$ was applied for $4 \mathrm{~h}$. The protein bands in the PAGE gels were become visible by staining in a $0.1 \%$ coomassie brilliant blue R-250 solution, and quantified by a BioRad phosphoimaging autodensitometer. On the other hand, the products of $\mathrm{Hb}(1 \mu \mathrm{M})$ treated for $36 \mathrm{~h}$ at $50{ }^{\circ} \mathrm{C}$ by $\mathrm{Fe}_{2}(15 \mu \mathrm{M})$ in the buffer were directly assayed by LC-ESI-MS on an Agilent1100 Cap LC/MSD XCT mass spectrometer in positive ionization mode.

References

(1) Liu, C.; Yu, S.; Li, D.; Liao, Z.; Sun, X.; Xiu, H. Inorg. Chem. 2002, 41, 913-922.

(2) Pyle, A. M.; Rehmann, J. P.; Meshoyrer, R.; Kumar, C. V.; Turro, N. J.; Barton, J. K. J. Am. Chem. Soc. 1989, 111, 3053-3058; Shrivastava, H. Y.; Kanthimathi, M.; Nair, B. U.Biochimica. et. Biophysica. Acta. 2002, 1573, $149-155$

(3) Carlsson, U.; Aasa, R. L.; Henderson, E.; Jonsson, B. H.; Lindskog, S. Eur. J. Biochem. 1975, 52, 25-36. Porter, E. A.; Weisblum, B.; Gellman, S. H. J . Am. Chem. Soc. 2002, 124, 7324-7 
A

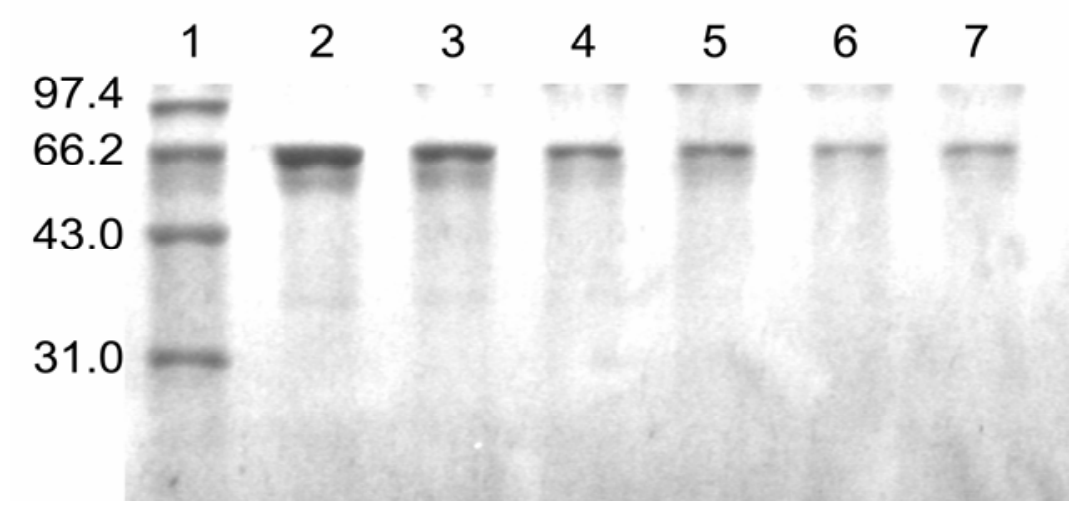

B

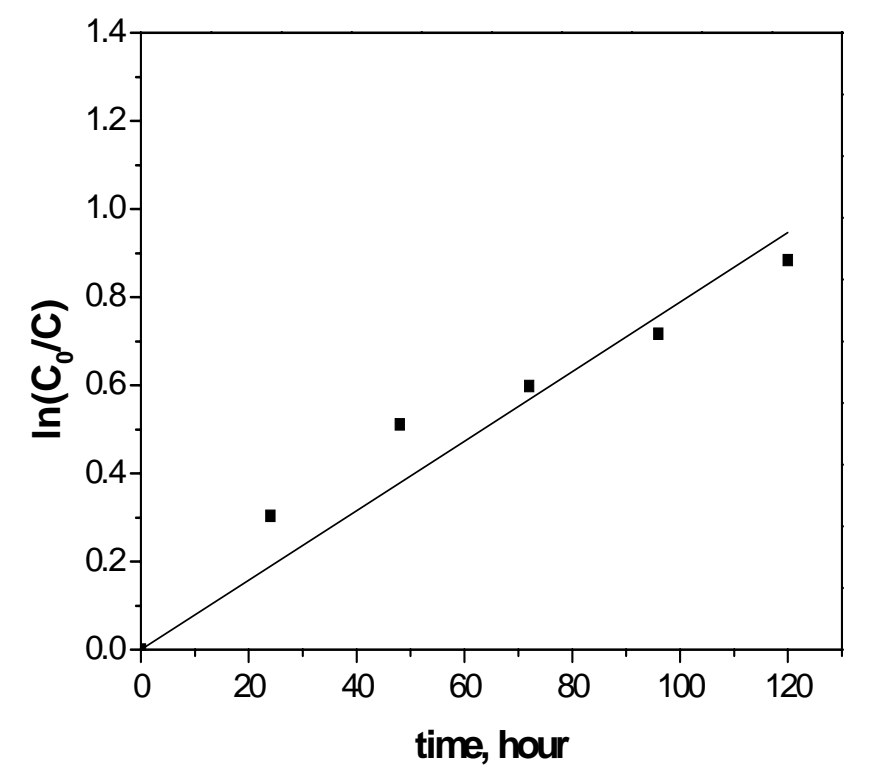

Figure S1. The time-dependence of natural BSA hydrolysis by $\mathrm{Fe}_{2}$ under the anaerobic conditions. (A) The reactions contained $5 \mu \mathrm{M}$ BSA, $150 \mu \mathrm{M} \mathrm{Fe} e_{2}$ in $20 \mathrm{mM} \mathrm{HAc-NaAc}$ buffer, pH5.6, and were incubated for 0 (lane 2), 24 (lane 3), 48 (lane 4), 72 (lane 5), 96 (lane 6), and $120 \mathrm{~h}$ (lane 7), respectively, at $50^{\circ} \mathrm{C}$. (B) The plot of $\ln \left(\mathrm{C}_{0} / \mathrm{C}\right)\left(\mathrm{C}_{0}\right.$ and $\mathrm{C}$ represent the concentrations of BSA at the initiation and at any moment of the reactions, respectively) against reaction time. 
A

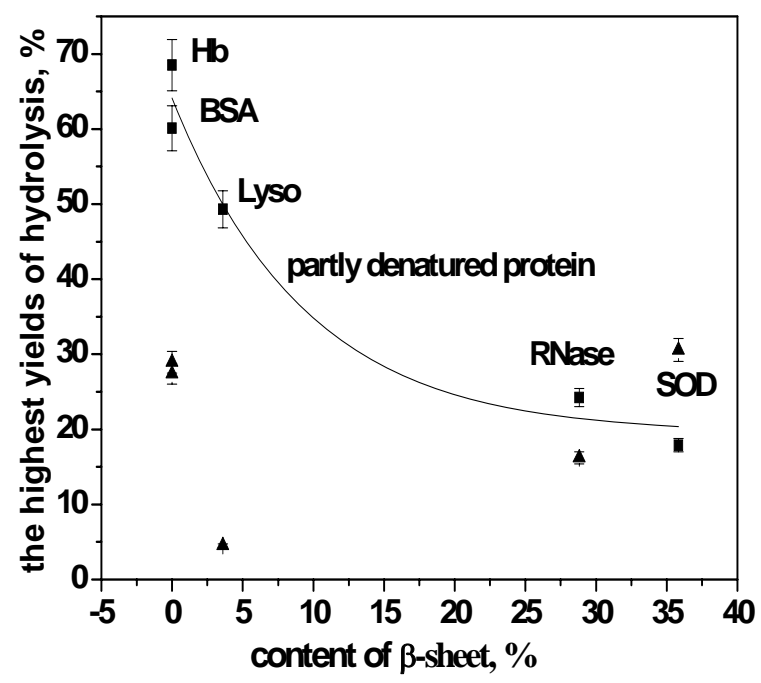

B

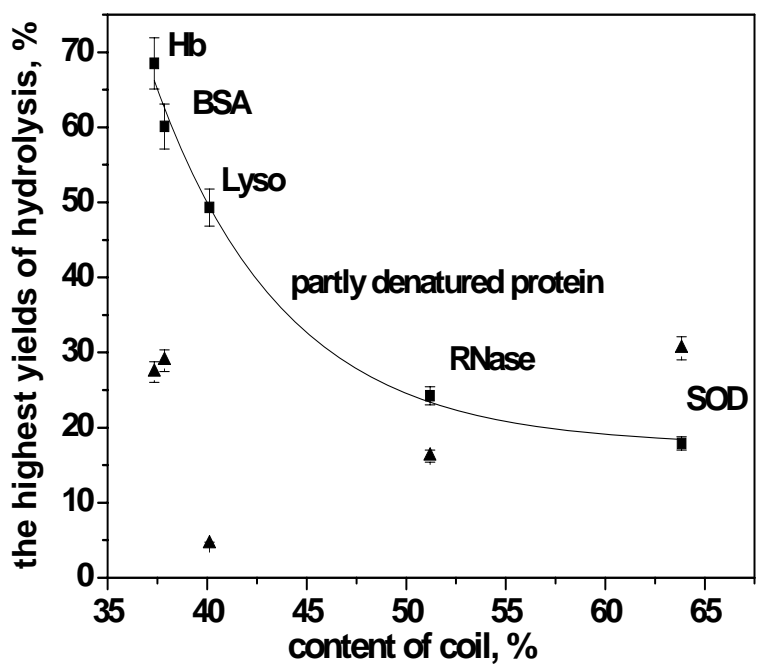

Figure S2. The plots of the highest hydrolytic yields by a given amount of $\mathrm{Fe}_{2}$ in a given period for both the native ( $\boldsymbol{\Delta})$ and the partly denatured ( $\boldsymbol{(})$ forms of five proteins against the contents of their $\beta$-sheet (A) and coil structures (B). The contents of secondary structures in the proteins were estimated by using the data in PDB (PDB ID: Hb, 1GO9; BSA, 1AO6; Lyso, 1AKI; RNase, 1RCA; SOD, 1E9Q). 